\title{
Treatment of advanced vascular lesions in the central region of the face by transdermal radiofrequency thermal ablation
}

\author{
Leczenie zaawansowanych zmian naczyniowych centralnej części twarzy \\ przezskórną termoablacją radiową
}

\author{
Joanna Borecka-Sobczak', Wioletta Barańska-Rybak² \\ 'Phlebology Outpatient Clinic, Gdańsk, Poland \\ 2Department of Dermatology, Venereology and Allergology, Medical University of Gdańsk, Poland \\ 'Poradnia Flebologiczna w Gdańsku, Polska \\ 2Klinika Dermatologii, Wenerologii i Alergologii Gdańskiego Uniwersytetu Medycznego, Polska
}

Dermatol Rev/Przegl Dermatol 2018, 105, 314-320

DOI: https://doi.org// 0.5 | |4/dr.2018.75587

\author{
CORRESPONDING AUTHOR/ \\ ADRES DO KORESPONDENCJI: \\ lek. Joanna Borecka-Sobczak \\ Poradnia Flebologiczna \\ ul. Partyzantów 27 \\ 80-254 Gdańsk, Polska \\ tel.: +4850857918 \\ e-mail: jborecka-sobczak@wp.pl
}

\begin{abstract}
Telangiectasias are commonly found on the face because of its rich innervation, intensive vascular peristalsis as well as a relatively large number of blood vessels and their more superficial location in the facial area. This article presents the case of a patient with advanced vascular lesions on the face, also in the form of small varices below the nose which have been increasing in severity for many years. Such lesions are infrequent in this location, but difficult to treat. Haemangioma involving craniofacial structures was excluded prior to treatment. Transdermal monopolar radiofrequency thermal ablation was used, which proved to be an effective method of removing advanced facial vascular lesions. An indisputable advantage of the method is the fact that it does not require skin needeling. Radiofrequency thermocoagulation involves solely touching the skin with the tip of a needle. The method requires a number of procedures but there is no need for analgesia, and the treatment is comfortable and safe for the patient. A total of 25 procedures were performed, each with the power of 13-15 W, with an average of 800 pulses per procedure. No recurrence was observed after a year of follow-up.
\end{abstract}

\section{STRESZCZENIE}

Teleangiektazje na skórze twarzy są częste ze względu na bogate unerwienie i żywą grę naczyniową oraz stosunkowo dużą liczbę naczyń i ich płytsze położenie w tej lokalizacji. W pracy opisano przypadek pacjentki z nasilającymi się od wielu lat zaawansowanymi zmianami naczyniowymi na twarzy, również w postaci niewielkich żylaków poniżej nosa. Powyższe zmiany nie są częste w tej okolicy, są jednak trudne do usunięcia. Przed leczeniem wykluczono naczyniaka obejmującego struktury twarzoczaszki. Zastosowano przezskórną termoablację z użyciem monopolarnej fali radiowej, która okazała się skuteczną metodą likwidacji zaawansowanych zmian naczyniowych na twarzy. Zaletą metody jest to, że nie wymaga nakłuć i odbywa się poprzez dotknięcie skóry igłą. Wymaga to wielu zabiegów przeprowadzanych w sposób bezpieczny i komfortowy dla pacjenta, bez potrzeby znieczulenia. Łącznie wykonano 
25 zabiegów z zastosowaniem mocy 13-15 W oraz średnio 800 impulsów podczas zabiegu. Po roku od zabiegu nie zaobserwowano nawrotu zmian.

Key words: vascular lesions, face, telangiectasias, radiofrequency thermocoagulation.

Słowa kluczowe: zmiany naczyniowe, twarz, teleangiektazje, termokoagulacja falami radiowymi.

\section{INTRODUCTION}

Blood is supplied to the skin of the face via branches of the external carotid artery, the walls of which are highly innervated with nerve fibres belonging to the external carotid plexus. Since the face is richly innervated, the region demonstrates intensive vascular peristalsis. The facial area has multiple arteriovenous connections which can become dilated in response to a variety of physical and chemical factors. The vascular pattern in the skin of the face is characterized by a relatively large number of blood vessels per skin volume unit. Consequently, the volume of the cutaneous vascular bed in this area is much higher than in other body regions. As blood vessels in the face are located more superficially - just under the epidermal surface - their dilation is visible [1].

Transdermal radiofrequency thermal ablation involves the application of monopolar or bipolar radiofrequency energy which is converted into thermal energy inside veins, closing them in the process of thermal coagulation. In the case described here, monopolar radiofrequency energy was applied. The procedure was performed using needles with diameters of $0.150 \mathrm{~mm}$ and $0.075 \mathrm{~mm}$, which are most frequently used for the transdermal closure of spider veins on the lower extremities and the face, respectively [2].

\section{OBJECTIVE}

The aim of the study is to present the case of a female patient with vascular lesions on the face who was treated by transdermal monopolar radiofrequency ablation.

\section{CASE REPORT}

An 81-year-old woman presented with dilated vascular vessels on the face, involving the region of the nasal ala and dorsum, and the medial cheeks, as well as small varices elevated above the skin surface

\section{WPROWADZENIE}

Krew do skóry twarzy dostarczana jest z odgałęzień tętnicy szyjnej zewnętrznej, której ściany są silnie unerwione przez włókna należące do splotu nerwowego szyjno-tętniczego zewnętrznego. Bogate unerwienie w obszarze twarzy umożliwia żywą grę naczyniową w tej okolicy. Obecne są tu liczne połączenia tętniczo-żylne, dlatego pod wpływem różnych czynników natury fizycznej i chemicznej mogą się one poszerzyć. Układ naczyniowy skóry twarzy charakteryzuje się stosunkowo dużą liczbą naczyń w przeliczeniu na jednostkę objętości skóry, co powoduje, że pojemność skórnego łożyska naczyniowego w tym rejonie jest znacznie większa niż w innych częściach ciała. Płytkie położenie naczyń w tej lokalizacji - zaraz pod powierzchnią naskórka - sprawia również, że rozszerzenie naczyń jest widoczne [1].

Przezskórna termoablacja radiowa polega na zastosowaniu monopolarnej lub bipolarnej energii fali radiowej, która zamieniana jest w żyle na energię cieplną, zamykając naczynie na drodze koagulacji (termokoagulacja). W opisywanym przypadku została użyta monopolarna energia fali radiowej, zastosowano igły o średnicy 0,150 mm i 0,075 mm najczęściej przeznaczone do przezskórnego zamykania rozszerzeń drobnych naczyń krwionośnych kończyn dolnych i twarzy [2].

\section{CEL PRACY}

Celem pracy jest przedstawienie opisu przypadku chorej leczonej z powodu zmian naczyniowych skóry twarzy metodą przezskórnej ablacji monopolarną energią fali radiowej.

\section{OPIS PRZYPADKU}

Kobieta 81-letnia zgłosiła się z powodu poszerzonych naczyń żylnych na twarzy w okolicy skrzydełek i grzbietu nosa, przyśrodkowej części policzków oraz niewielkich żylaków zlokalizowanych na skórze wargi górnej oraz w przedsionku nosa, wyniosłych nad 
to $0.5 \mathrm{~cm}$, located on the skin of the upper lip and projecting into the nasal vestibule.

The lesions appeared 60 years before (in 1956), after a natural childbirth. As the patient reported, the lesions manifested as multiple red telangiectasias.

In the course of time, they became more severe. A number of therapies were tried at that time, including cryotherapy, laser therapy and electrocoagulation, in courses of 10 procedures, in various medical centres, but failed to produce the desired effect. The patient was referred for consultation to the Hospital in Polanica-Zdrój for consideration of the possibility of skin grafting. The patient decided against the treatment because of the uncertainty of effect and the risk of complications.

Searching for other therapeutic options, the patient presented to our outpatient clinic in June 2014 with the lesions described above, the sensation of swelling in the nose and mental discomfort. For many years, the patient had not left her house without covering up the lesions with theatrical foundations (fig. 1).

Prior to the commencement of treatment the patient was referred for a consultation with a laryngologist and for magnetic resonance imaging (MRI) of the head. The laryngological examination revealed a fragment of haemangioma projecting into the nasal vestibule for $0.5 \mathrm{~cm}$ on the right side at the septal powierzchnię skóry (ok. 0,5 cm). Zmiany pojawiły się ponad 60 lat temu (w $1956 \mathrm{r}$.) po porodzie siłami natury. Jak wynika z relacji pacjentki, miały postać licznych teleangiektazji barwy czerwonej.

Zmiany ulegały nasileniu. Przeprowadzano zabiegi krioterapii, laseroterapii, elektrokoagulacji, w seriach po 10, w różnych ośrodkach, jednak nie uzyskano oczekiwanego efektu. Chorą skierowano do szpitala w Polanicy-Zdroju w celu konsultacji możliwości przeszczepienia skóry. Pacjentka zrezygnowała z podjęcia tego leczenia ze względu na niepewny wynik i ewentualne powikłania.

Chora, poszukując dalszych możliwości leczenia, trafiła do naszej poradni w czerwcu 2014 r. z opisanymi wyżej zmianami oraz uczuciem obrzekku w nosie. Zmianom skórnym towarzyszył dyskomfort psychiczny, pacjentka od wielu lat nie wychodziła z domu bez maskującego makijażu (ryc. 1).

Przed rozpoczęciem leczenia zlecono konsultację laryngologiczną i rezonans magnetyczny głowy ( $m a-$ gnetic resonance - MR). W badaniu laryngologicznym uwidoczniono fragment naczyniaka przy słupku przegrody nosowej po prawej sronie, który wchodził do przedsionka nosa na głębokość $0,5 \mathrm{~cm}$, głębiej nie stwierdzono zmian. Angiografia tomografii komputerowej (angio-TK) głowy, którą pacjentka wykonała wcześniej (w 2013 r.), i MR głowy (w 2014 r.) wyka-

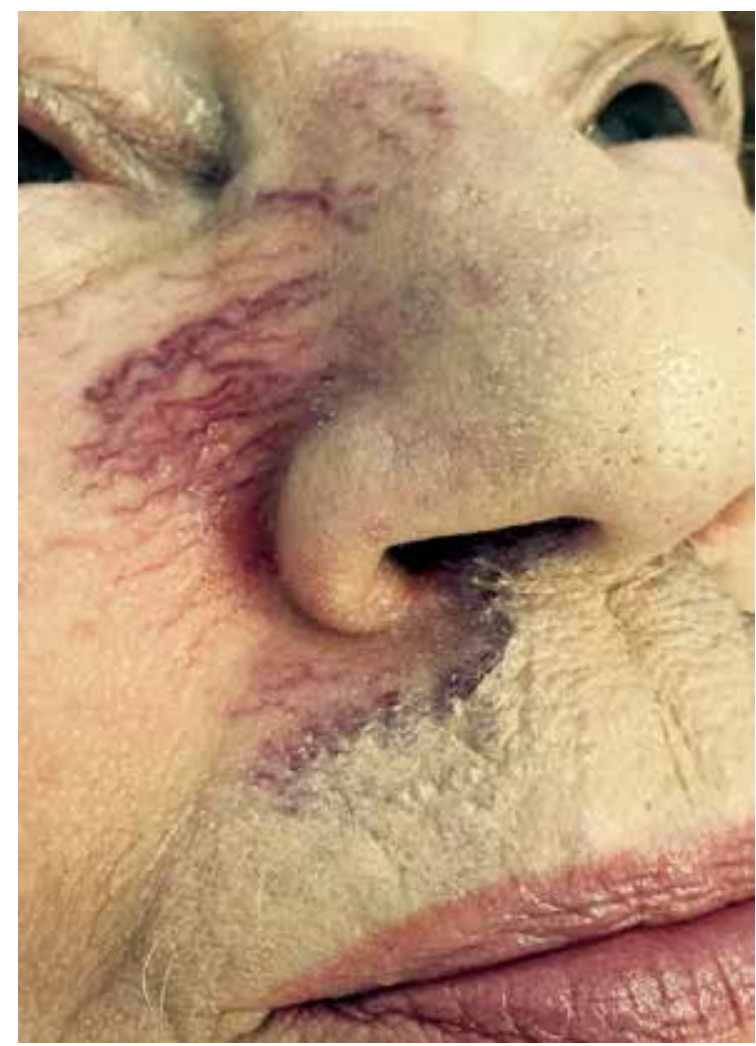

Figure I. Before treatment - May 2015

Rycina I. Przed leczeniem - maj $2015 \mathrm{r}$. 
columella. However, no abnormalities were found intranasally. Computed tomography angiography (angio-CT) of the head, which was performed earlier (2013), and MRI of the head (2014) showed stationary lesions presenting as middle cerebral artery aneurysms, without pathologies in the sinuses or blood vessels within the soft tissues in the nasal region.

Based on the patient's history, she was treated for arterial hypertension (bisoprolol $1 \times 5 \mathrm{mg}$, losartan $1 \times 50$ $\mathrm{mg}$, furosemide $1 \times 40 \mathrm{mg}$, potassium chloride $2 \times$ per week $391 \mathrm{mg}$, simvastatin $1 \times 10 \mathrm{mg}$ and acetylsalicylic acid $1 \times 75 \mathrm{mg}$ ). The patient also had two surgeries for varicose veins of the lower limbs (40 years previously).

\section{Treatment}

The patient was offered treatment based on the coagulation of lesions by transdermal radiofrequency thermal ablation. She was informed about the risk of treatment failure and possible complications. The patient signed an informed consent form to undergo the therapeutic procedure.

The procedures were initiated in May 2015, using a needle with a diameter of $0.075 \mathrm{~mm}$ dedicated for facial treatment, delivering pulses at a power level of 8-10 $\mathrm{W}$ (recommended for facial blood vessels). Importantly, the skin was only touched with the needle, without puncturing. After several procedures performed on the skin of the upper lip the effects were not satisfactory. Consequently, a decision was made to apply a needle with a diameter of $0.150 \mathrm{~mm}$, dedicated for the treatment of vascular lesions in the lower extremities, delivering an average of 800 pulses at a power level of 10-15 $W$ per procedure. In the initial treatment phase, the vessels became narrower, and then closed. After summer breaks the vessels were found to have reappeared, however they were much narrower. No elevated lesions were seen any more.

A total of 25 procedures were performed (May 2015 - June 2016), achieving the desirable outcome, particularly in terms of the aesthetic effect which was so important for the patient, without scars and discoloured skin. Also, the sensation of "swelling in the nose" previously reported by the patient was eliminated (figs. 2, 3).

\section{Effects}

The patient reported for a follow-up visit in March 2017. No exacerbation of the disease was observed. At present, the patient is continuing the treatment of small lesions in the form of spider veins.

\section{DISCUSSION}

The presented case is unique in that vascular lesions which, in this region, usually present as ery- zały zmiany stacjonarne w postaci tętniaków tętnic środkowych mózgu, bez patologii zatok i naczyń tkanek miękkich okolicy nosa.

Pacjentka była leczona $\mathrm{z}$ powodu nadciśnienia tętniczego (bisoprolol $1 \times 5 \mathrm{mg}$, losartan $1 \times 50 \mathrm{mg}$, furosemid $1 \times 40 \mathrm{mg}$, chlorek potasu $2 \times$ w tygodniu $391 \mathrm{mg}$, simwastatyna $1 \times 10 \mathrm{mg}$ i kwas acetylosalicylowy $1 \times 75 \mathrm{mg}$ ). Chora została poddana dwóm zabiegom chirurgicznym z powodu żylaków kończyn dolnych (40 lat temu).

\section{Leczenie}

Chorej zaproponowano koagulację zmian przezskórną termoablacją radiową, informując o możliwości niepowodzenia i powikłaniach. Pacjentka podpisała świadomą zgodę na powyższą procedurę terapeutyczną.

Zabiegi rozpoczęto w maju 2015 r., używając igły o średnicy 0,075 mm z zastosowaniem impulsów o mocy 8-10 W (moc również zalecana do naczyń na twarzy). Należy zaznaczyć, że skóry jedynie dotykano igła, nie nakłuwano. Po kilku zabiegach na skórze wargi górnej nie uzyskano zadowalających efektów. Wówczas zdecydowano o użyciu igły o średnicy 0,150 mm przeznaczonej do leczenia zmian naczyniowych na nogach z zastosowaniem mocy 10-15 W i średnio 800 impulsów podczas zabiegu. W początkowej fazie leczenia naczynia stopniowo zwężały się, a następnie zamykały. Po okresach letnich przerw obserwowano odtwarzanie się naczyń, jednak dużo węższych. Nie stwierdzono już zmian wypukłych.

Łącznie wykonano 25 zabiegów (maj 2015 r. czerwiec 2016 r.), uzyskując oczekiwany bardzo ważny dla pacjentki efekt estetyczny, bez blizn i przebarwień. Zniknęło również opisywane wcześniej przez pacjentkę uczucie obrzęku w nosie (ryc. 2, 3).

\section{Efekty}

Pacjentka zgłosiła się ponownie w marcu 2017 r. Nie zauważono nasilenia się zmian. Obecnie chora kontynuuje leczenie drobnych zmian naczyniowych.

\section{OMÓWIENIE}

Prezentowany przypadek jest szczególny, ponieważ zmiany naczyniowe, zwykle występujące w tej okolicy postać rumienia lub niewielkich teleangiektazji, u pacjentki wytworzyły żylaki wyniosłe ponad powierzchnię skóry wargi górnej oraz na pozostałym zajętym obszarze wyraźne, szerokie (ok. $1 \mathrm{~mm}$ ) teleangiektazje. U pacjentki nie uzyskano poprawy po wcześniej zastosowanym leczeniu. W dostępnym piśmiennictwie nie istnieje wiele opisów przypadków terapii żylaków wargi górnej. 


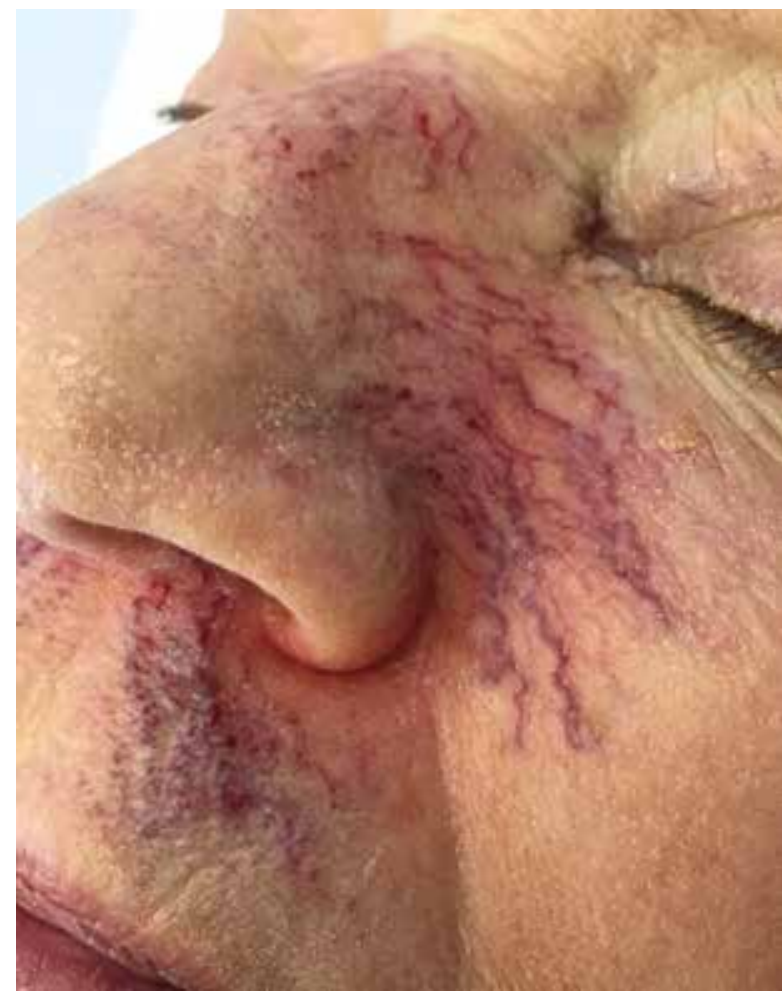

Figure 2. During treatment - June 2015

Rycina 2. W trakcie leczenia - czerwiec 2015 r.

thema or small telangiectasias, in the discussed patient manifested as varices elevated above the surface of the skin on the upper lip and marked broad (approximately $1 \mathrm{~mm}$ ) telangiectasias on the skin of the remaining involved area. In addition, previous treatment brought no improvement, and the available medical literature contains few case reports on the treatment of varices of the upper lip.

The most frequently recommended treatment for facial spider veins is laser therapy. Important factors to consider include wavelength selection, pulse duration and energy density. The treatment is very frequently conducted using a neodymium YAG (Nd:YAG) laser with a wavelength of 1,064 nm. On account of its good therapeutic effects, easy access and short duration of treatment, laser therapy is among the most commonly selected methods for the treatment of facial telangiectasias. The treatment can also be performed with a modified $\mathrm{Nd}$ :YAG laser with a wavelength of $532 \mathrm{~nm}$. It is used in the therapy of red vascular lesions. The closure of blood vessels can also be achieved using a pulsed dye laser (PDL) with a wavelength range of 577-585 $\mathrm{nm}$. The treatment is applied until the lightening of lesions [2-5].

There are also two case reports of patients with isolated facial malformations receiving a therapy with a Nd:YAG laser with a wavelength of 1,444 nm. The procedure proved highly effective, however skin

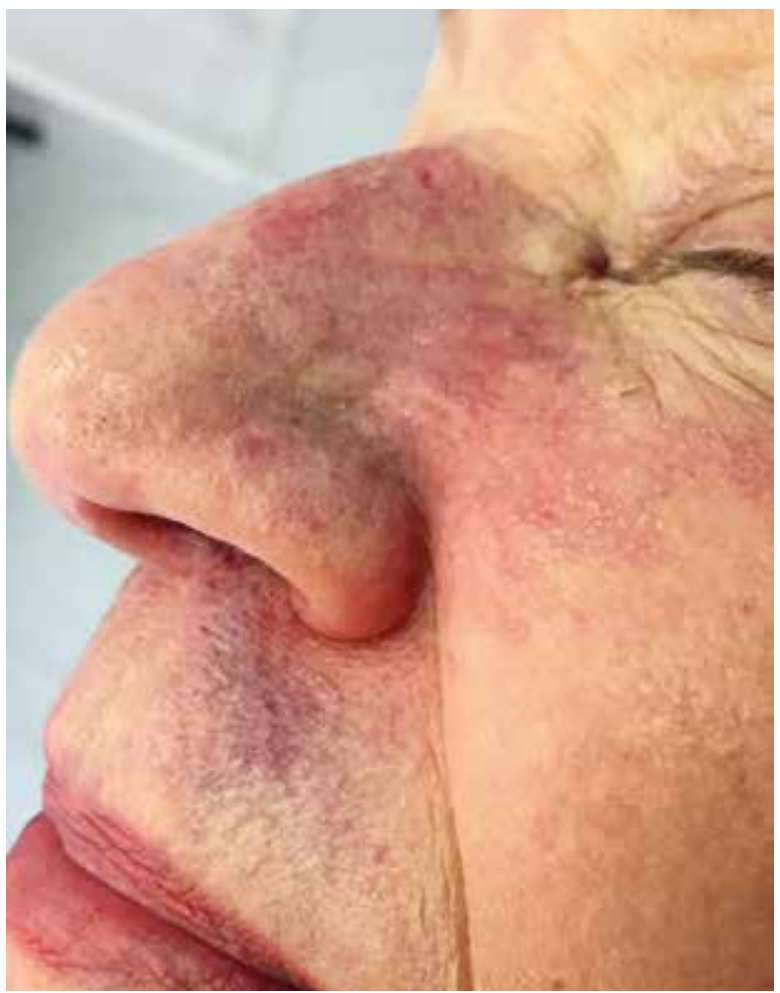

Figure 3. After treatment - June 2016

Rycina 3. Po leczeniu - czerwiec $2016 \mathrm{r}$.

Najczęściej zalecaną metodą w leczeniu poszerzonych drobnych naczyń krwionośnych na twarzy jest terapia laserowa. Ważny okazuje się dobór odpowiedniej długości fali, czasu trwania impulsu oraz gęstości energii. Bardzo często stosuje się laser neodymowo-yagowy (Nd-YAG) o długości fali $1064 \mathrm{~nm}$. Osiąganie dobrych efektów terapeutycznych, łatwość dostępu oraz krótki czas trwania zabiegu powodują, że metoda laserowa jest jedną z najczęściej wybieranych technik w przypadku teleangiektazji twarzy. Wykorzystuje się też laser o długości fali $532 \mathrm{~nm}$. Jest to zmodyfikowany Nd-YAG. Stosuje się go w leczeniu zmian naczyniowych barwy czerwonej. Kolejnym laserem służącym do zamknięcia naczyń jest laser barwnikowy (pulsed dye laser - PDL) o długości fali $577 \mathrm{~nm}$ do $585 \mathrm{~nm}$. Zabieg wykonuje się do momentu przejaśnienia zmian [2-5].

Opisano dwa przypadki pacjentów z izolowanymi malformacjami twarzy leczonych laserem Nd-YAG o długości fali 1444 nm, która to procedura była bardzo skuteczna, ale ze względu na konieczność nakłuwania skóry wymagała znieczulenia z blokadą nerwu [6].

Skleroterapia, która jest dobrą i skuteczną metodą leczenia zmian tej wielkości, jest niestety bardzo inwazyjna, a dodatkowo ze względu na liczne połączenia tętniczo-żylne naczyń na twarzy istnieje ryzyko rozwoju martwicy skóry $[7,8]$. 
puncturing was used, which necessitated nerve-block analgesia [6].

Sclerotherapy, a good and effective method of treating lesions of this size, is unfortunately highly invasive. In addition, the presence of multiple arteriovenous connections of facial blood vessels creates the risk of skin necrosis $[7,8]$.

Radiofrequency thermal ablation is an alternative method to laser therapy. It is less painful and can be used regardless of skin phototype. It has applications in the treatment of broader vessels. What is more, it does not cause scarring, which was the primary reason for selecting this modality for the treatment of our patient who was frustrated by the inefficacy of previous therapies. The literature contains case reports of successful treatment by bipolar radiofrequency thermal ablation combined with polychromatic light (intense puls light - IPL), referred to as ELOS technology (Electro-Optical Synergy; LED laser with radiation), however the cases described involved erythema and small telangiectasias. The method was found to be more effective than IPL alone. Follow-up periods ranged from 1 month to 3 months after treatment [9].

In addition, there is a published case report of the treatment of telangiectasia on the skin of the nose in a patient with Osler-Weber-Rendu disease using bipolar radiofrequency pulses delivered at a power level of $30 \mathrm{~W}$. The lesions were successfully removed after 4 sessions, and no recurrence was noted for 2 years. It was necessary to use the skin-puncturing procedure and local analgesia [10].

\section{CONCLUSIONS}

The therapy of vascular lesions requires patience and a careful selection of treatment, since patients view the condition not only as an aesthetic problem but also a psychological one, which is made worse by the fear of complications including scarring. Transdermal radiofrequency thermal ablation is an effective, safe and minimally invasive therapeutic modality, and should be considered in all patients requiring the treatment of facial vascular lesions.
Termoablacja radiowa jest terapią alternatywną do metod laserowych. Metoda ta jest mniej bolesna i można ją stosować niezależnie od fototypu skóry. Znajduje zastosowanie w przypadku naczyń szerszych. Nie powoduje bliznowacenia, co było głównym powodem wyboru tej metody u pacjentki zniechęconej do wcześniejszych terapii. W piśmiennictwie przedstawiono przypadki satysfakcjonującego leczenia termoablacją przy użyciu fali radiowej bipolarnej w połączeniu ze światłem polichromatycznym (intense puls light - IPL), tzw. technologia ELOS (electro-optical synergy; laser diodowy z radiacją), jednak dotyczyły one rumienia i drobnych teleangiektazji. Była to metoda skuteczniejsza od leczenia wyłącznie IPL. Obserwacje prowadzono od 1 miesiąca do 3 miesięcy po terapii [9].

Opisano również przypadek leczenia teleangiektazji na skórze nosa u pacjenta z chorobą Rendu-Oslera-Webera przy użyciu bipolarnej fali radiowej o mocy impulsów $30 \mathrm{~W}$. Zmiany usunięto po 4 sesjach, a brak nawrotów obserwowano przez kolejne 2 lata. Niezbędne było zastosowanie nakłuć i znieczulenia miejscowego [10].

\section{WNIOSKI}

Terapia zmian naczyniowych wymaga cierpliwości i starannego wyboru metody leczenia. Dla pacjenta jest to nie tylko problem estetyczny, lecz także psychologiczny. Dodatkowo pacjentowi towarzyszy obawa przed powikłaniami, w tym bliznowaceniem. Przezskórna termoablacja radiowa jest metodą efektywną, bezpieczną oraz małoinwazyjną i należy ją rozważyć w każdym przypadku leczenia zmian naczyniowych twarzy.

\section{KONFLIKT INTERESÓW}

Autorzy nie zgłaszają konfliktu interesów.

\section{CONFLICT OF INTEREST}

The authors declare no conflict of interest.

\section{References}

Piśmiennictwo

1. Ratajczak-Stefańska V., Maleszka R., Boer M., Kiedrowicz M.: Skóra naczyniowa - problemy diagnostyczne. Roczniki Pomorskiej AM w Szczecinie 2009, 55, 58-65.

2. Goldberg D.J.: Lasery i światło. Vol. 1. Elsevier Urban\&Partner, Wrocław 2010.

3. Peszyński-Drews C.: Lasery i laseroterapia od A do Z. „M” jak „mechanizm” efekty i mechanizmy biologicznej interakcji światła laserowego z materią żywą. Dermatol Estet 2007, 9, 302-304.

4. Kaszuba A., Halbina A.: Zmiany naczyniowe i ich leczenie z użyciem laserów. Dermatol Estet 2008, 10, $278-282$. 
5. Ozyurt K., Colgecen E., Baykan H., Ozturk P., Ozkose M.: Treatment of superficial cutaneous vascular lesion: experience with the long-pulsed $1064 \mathrm{~nm}$ Nd:YAG laser. Sci World J 2012, 2012, 197139.

6. Radmanesh M., Radmanesh R.: Successful treatment of isolated venous malformation with 1444-nm fiberoptic Nd-YAG laser. J Cosmet Laser Ther 2016, 18, 91-94.

7. Hoffman K.: An unusual complication of facial sclerotherapy. Dermatol Surg 2003, 29, 423-424.

8. Yiannakopoulou E.: Safety concerns for sclerotherapy of telangiectases, reticular and varicose veins. Pharmacology 2016, 98, 62-69.

9. Taub A.F., Devita E.C.: Successful treatment of erythematotelangiectatic rosacea with pulsed light and radiofrequency. J Clin Aestet Dermatol 2008, 1, 37-40.

10. Byun S.Y., Kim B.R., Park J.T., Chae J.B., Na J.I.: A simple and effective treatment for nasal telangiectasia: needle-assisted electrocoagulation. J Am Acad Dermatol 2016, 74, e49-e50.

Received: 6.09.2017

Accepted: 28.01 .2018

Otrzymano: 6.09.2017 r.

Zaakceptowano: $28.01 .2018 \mathrm{r}$.

How to cite this article

Borecka-Sobczak J., Barańska-Rybak W.: Treatment of advanced vascular lesions in the central region of the face by transdermal radiofrequency thermal ablation. Dermatol Alergol/Przegl Dermatol 2018, 105, 314-320. DOI: https://doi.org/10.5114/dr.2018.75587. 